\title{
Effect of using insects as feed on animals: pet dogs and cats
}

\author{
G. Bosch ${ }^{1 *}$ and K.S. Swanson ${ }^{2,3,4}$ \\ ${ }^{1}$ Animal Nutrition Group, Wageningen University \& Research, De Elst 1, 6708 WD Wageningen, the Netherlands; ${ }^{2}$ Department \\ of Animal Sciences, University of Illinois at Urbana-Champaign, Urbana, IL 61801, USA; ${ }^{3}$ Division of Nutritional Sciences, \\ University of Illinois at Urbana-Champaign, Urbana, IL 61801, USA; ${ }^{4}$ Department of Veterinary Clinical Medicine, \\ University of Illinois at Urbana-Champaign, Urbana, IL 61801, USA; guido.bosch@wur.nl
}

Received: 20 July 2020 / Accepted: 19 October 2020

(c) 2020 Wageningen Academic Publishers

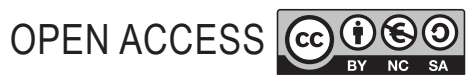

REVIEW ARTICLE

\begin{abstract}
The 'buzz' in society around insects has resulted in the appearance of insect-based pet food products on the market and more products are under development. This contribution aimed to provide background information on pet foods and the sector and to provide an overview of the current state of knowledge regarding naturalness, palatability, nutritional quality, health effects, and sustainability of insects as feed for dogs and cats. In contrast to dogs, natural diets of cats commonly contain insects but contribution to the total biomass is $<0.5 \%$ in most diets. Cats and dogs can have a different palate when it comes to insects and insect species and inclusion level influence the acceptance of the food. The apparent faecal $\mathrm{N}$ digestibility values for insect-based foods were in the range of foods containing conventional protein sources. Based on the indispensable amino acid (IAA) digestibility values reported for black soldier fly larvae (BSFL), housefly larvae (HFL), and yellow mealworms (YMW) in chickens and requirements of growing dogs and growing cats, the first limiting IAA were methionine (BSFL, dogs and cats; YMW, dogs and cats), threonine (BSFL, dogs), and leucine (HFL, dog and cats). More long-term studies are still required to evaluate adequacy and safety of insect-based pet foods in dogs and cats as well as studies that focus on the presence of health-promoting biofunctionalities of insects. Insect proteins have a lower environmental impact than livestock meat proteins, but this is not relevant in the context of pet foods that are largely based on animal co-products with a low environmental impact. Developments in insect rearing will make insect proteins more competitive with conventional sources. For advancing insect applications beyond hypoallergenic pet foods, it will be essential to assure insects as safe and quality ingredients as well as understanding pet owner views and values regarding insect rearing.
\end{abstract}

Keywords: health, naturalness, nutritional quality, palatability, sustainability

\section{Introduction}

Pet dogs (Canis familiaris) and cats (Felis silvestris catus) play an important role in many people's lives around the globe. Pet-ownership is considerable with over 170 million dogs and 190 million cats living in households in Europe and the USA (FEDIAF, 2019a; Statista, 2020a,b) and increasing numbers in particularly in Asia and Latin America. Pets provide companionship, affection and protection and owners value the unique bonds they have with their pets and their contribution to the quality of life (O'Haire, 2010; Podberscek et al., 2000). Furthermore, pets are commonly viewed as family members and as equals, which has important consequences for the development and marketing of pet foods. Trends in human food, for example, are often rapidly translated into new pet food products. Insects have received considerable attention as a sustainable and sometimes even health-promoting and novel protein source for humans. The 'buzz' in society around insects has also resulted in the appearance of insect-based pet food products on the market and more products are on their way. This contribution aims to provide background information on pet foods as well as the current state of knowledge regarding some features of insects as feed for dogs and cats. 


\section{Pet foods}

Today's pet owner's can choose from a plethora of nutritious products to support specific breeds and sizes, particular life stages, and disease predispositions, in various formats and packaging styles, and for different prices. Owners often decide to buy a specific pet food based on price, convenience, previous experience, packaging, brand reputation, and marketing claims. Furthermore, healthfulness, freshness and ingredients of a pet food are evaluated by owners (Schleicher et al., 2019). Specific ingredients are associated with nutritional quality such as the presence of 'natural' ingredients (Vinassa et al., 2020). Familiar phrases, popular trends and beliefs on packaging and advertisements also help to attract owners to products. These trends in pet food products often follow those in human nutrition. Examples of trends are grain-free and 'natural' pet foods (Beaton, 2014; Wall, 2018). Supposed health benefits to pets of such trendy feeding practices are often not supported by scientific studies (Schleicher et al., 2019) and might even be associated with health concerns for the pet (grain-free foods were initially accused to be related to canine dilated cardiomyopathy) and social environment (raw foods potentially containing pathogenic bacteria). When consumer trends get ahead of the science and novel pet food products get associated with pet health problems, the reputation of an ingredient and/or the entire pet food industry may be negatively affected. Therefore, ingredients should undergo sufficient safety and efficacy testing before being incorporated into pet foods.

Once the food is in the bowl, its palatability is essential not only for its acceptance but also its enjoyment by the pet. For the owner, the moment of feeding contributes to the establishment and maintenance of the bond with the pet (Bradshaw and Cook, 1996; Day et al., 2009). Palatability of pet foods is therefore a key attribute. After consumption, effects on stool quality, coat condition, and more are monitored by owners and contribute to the success of a pet food. As the pet dog and cat are often fully dependent on the provision of food by their owners, it is essential that manufacturers provide appropriate and safe nutrition for health and longevity.

Of the different formats, the dry and moist foods are the most popular among pet owners in Western countries. During the manufacturing of these types of pet foods, thermal treatments like extrusion and retorting are used to improve the safety, shelf-life and nutritive properties of the foods but also to create the optimal texture and shape of the product (Hendriks et al., 1999). Although the diversity in available products is immense, the main protein sources used are similar and come from the rendering industry. For dry extruded foods, meat and by-product meals of poultry, beef, pig, lamb and fish are most commonly used. For wet retorted foods, proteins mainly originate from fresh and/or frozen meats and other animal tissues. Pet food quality attributes can be assessed with specific tests. Acceptance of a food as a measure of palatability is generally evaluated with a monadic test or a two-bowl test that evaluates the preference (relative palatability) for one food over another food (Aldrich and Koppel, 2015; Tobie et al., 2015).

The nutritional quality of a food or an ingredient depends largely on the presence of digestible and bioavailable nutrients, which should be present in amounts that assure requirements of the animal are met. Ingredients and complete foods can be chemically characterised to quantify the absolute amounts of the nutrients. Specific assays are used to estimate the degree of bioavailability of the nutrients. The standardised ileal digestibility assay, which is a routine methodology in production animal nutrition, was used in dogs decades ago but is no longer a routine procedure in the evaluation of pet foods due to ethical reasons and welfare issues. The apparent faecal digestibility assay, which is known to yield inaccurate estimates of the absorption of nutrients due to colonic fermentation (Hendriks et al., 2012), is commonly used. Standardised protocols are available for assessing apparent faecal digestibility (AAFCO, 2020; FEDIAF, 2019b). Furthermore, different in vitro assays varying in complexity (e.g. Hervera et al., 2009; Smeets-Peeters et al., 1999) and in vivo models such as the precision-fed cecectomized rooster assay (e.g. Faber et al., 2010; Johnson et al., 1998) and mink (e.g. Ahlstrøm and Skrede, 1998; Tjernsbekk et al., 2014) are also used to gain insight in nutrient digestibility or bioavailability of ingredients and complete foods. Finally, more long-term feeding protocols have been developed that aim to validate the adequacy of a pet food for the species and the life stage for which it is intended (growth, gestation/ lactation, maintenance; AAFCO, 2020).

The nutritional status and veterinary care of dogs and cats has greatly improved over the past few decades, improving the quality of life and extending the lifespan of pets. These changes have increased the number of geriatric pets in the population. While this is a positive outcome, aging comes with many ailments, including osteoarthritis, oral disease, cognitive dysfunction, and chronic kidney disease. Other diseases such as obesity, diabetes mellitus, lower urinary tract diseases, gastrointestinal diseases, and food sensitivity are also quite common in the pet population. Pet food companies have responded by developing therapeutic diets intended to aid in the management of these clinical disease states. The industry has also developed over-the-counter diets and treats to target specific functional areas of healthy pets. For over-the-counter pet products, the goal is to maintain the body's organ or system functionality, thereby supporting health and wellness. The primary functional areas targeted in these products include bones and joints, oral care, immunity, skin and coat, digestive health, odour control, hairball control, and cognitive function. 


\section{Insects as feed for pets}

\section{Naturalness}

Owners may prefer foods that match the ancestral history of their pet, assuming that they provide optimal nutrition. It is therefore of interest to consider the 'naturalness' of insects in the diet of dogs and cats. The dog is a direct descendent of the grey wolf (Canis lupus) (Leonard et al., 2002; Vilà et al., 1997), whereas the cat originates from the wildcat (Felis silvestris) in the Near East region (Driscoll et al., 2007). Wolves are carnivores that hunt in packs for large ungulates (e.g. deer, wild boar), but also opportunistically feed on smaller mammals (e.g. beavers, lagomorphs) (Bosch et al., 2015). Insects were reported to be present in 5 out 50 described diets of wild wolves, but with negligible contributions to the total biomass consumed (Bosch et al., 2015). Like most felids, domestic cats predominantly hunt individually. They hunt a variety of prey species, with rodents (e.g. mice, voles) and lagomorphs being most common, but birds, reptiles and insects can also be part of their diet (Malo et al., 2004; Pearre and Maass, 1998; Plantinga et al., 2011). Though insects were not specified by Plantinga et al. (2011), 26 out of the 30 diets contained invertebrates. In the review of Pearre and Maass (1998), 35 diets were presented for which the consumed insect biomass was estimated. The median proportion of insect biomass was only $0.5 \%$ of the total biomass of the diet. For four of the diets, however, insects contributed 13.6, 19.1, 20 and $21.9 \%$ to the total biomass consumed. Inspection of the original data revealed that the number ' $19.1 \%$ ' was the frequency of occurrence instead of biomass (Parmalee, 1953), the number '20\%' was actually $2 \%$ as described in the text of the original article (Llewellyn and Uhler, 1952), and the number '21.9\%' was not the contribution of insects to biomass eaten but the sum of dry weight of undigested fractions of grasshoppers, arachnids and beetles (Konecny, 1987). Based on the data provided by the latter author, the insects (i.e. grasshoppers + beetles) contributed $7.9 \%$ to the total dry biomass. The correctness of the remaining biomass estimates (13.6\%; Bayly, 1976) could not be verified as the manuscript was not available to us. In contrast to dogs, it seems that for some cats it is natural to consume some insects, but they should not be considered as insectivores that nutritionally depend on insects and are adapted to an insect-based diet.

\section{Palatability}

Though many companies likely have tested insect-based pet food prototypes internally, few data have been made public. It has been reported that dogs tended to prefer dry foods containing black soldier fly larvae (Hermetia illucens; BSFL) meal over those containing yellow mealworm (Tenebrio molitor; YMW) meal (intake ratio of 60:40; $\mathrm{n}=10$ ), whereas cats preferred the YMW-based food (40:60; n=10) (Beynen,
2018). Both insect meals contributed to $30 \%$ of total crude protein in these diets. Dogs have been shown to accept dry foods containing 5, 10 or $20 \%$ BSFL meal. In those 2-day studies, which might be too short to overcome a novelty effect, dogs $(n=20)$ readily consumed extruded foods containing 5 or 10\% BSFL meal, but only $93.9 \%$ of their estimated metabolisable energy requirements for maintenance with a 20\% inclusion level (Yamka et al., 2019). The latter study also reported that dogs fed kibbles coated with 2.5 or $5 \%$ BSFL oil consumed 91.5 and $116.2 \%$ of their metabolisable energy requirements, respectively. Including 8,16 or $24 \%$ banded cricket (Gryllodes sigillatus) meal in extruded foods did not affect food intake in dogs $(n=8)$ (Kilburn et al., 2020).

Three out of 10 cats had refused a food containing 35\% BSFL meal and three cats had an intake between 78 and $87 \%$ of the food offered (Paßlack and Zentek, 2018). For a food containing $22 \%$ BSFL meal, one cat vomited and then refused the food completely and two cats had lower food intakes (83 and 88\%) (Paßlack and Zentek, 2018). In cats fed a diet containing 5 or $20 \%$ of BSFL meal for 2 days ( $n=20$ per diet), 38 and $54 \%$ of the $100 \mathrm{~g}$ of food was consumed. None of the cats rejected the 5\% BSFL diet, whereas one cat rejected the $20 \%$ BSFL. Four cats fed the $5 \%$ BSFL diet ate less than $25 \mathrm{~g}$ on one of the 2 days, while this was observed for three cats fed the 20\% BSFL diet. The latter study also evaluated the acceptance of kibbles coated with 1, 2.5 or $5 \%$ BSFL oil. Of the 20 cats fed each food, food rejection on both days was observed for two (1\% BSFL oil), zero (2.5\% BSFL oil) and nine (5\% BSFL oil) cats, with five, seven and 16 cats consuming $<25 \%$ of their food. These studies illustrate that cats and dogs can have a different palate when it comes to insects and that insect species and inclusion level influence the acceptance of the food. Dogs seem to accept foods containing up to $10 \%$ BSFL meal and 24\% banded crickets as well as kibbles coated with up to $5 \%$ BSFL oil. Cats varied more in their acceptance of foods with BSFL meal or oil and seem to accept foods containing up to $5 \%$ BSFL or coated with up to $2.5 \%$ BSFL oil.

\section{Nutritional quality}

The variation in nutrient composition of insects has been investigated in numerous studies (for reviews see Makkar et al., 2014; Rumpold and Schlüter, 2013). As with conventional animal meals, nutrient composition varies among species and processing methods applied. Specific information on nutrient digestibility in dogs and cats has been published recently, though not all data originate from peer-reviewed studies (Table 1 ). In vitro $\mathrm{N}$ digestibility of freeze-dried ground BSFL, housefly larvae (Musca domestica; HFL), YMW and lesser mealworm (Alphitobius diaperinus) was approximately $90 \%$ and in the range of poultry meat meal (87.9\%) (Bosch et al., 2014, 2016). 
Table 1. Evaluation of in vitro and in vivo nitrogen digestibility of various insect meals as an ingredient for dog and cat foods. ${ }^{1}$

\begin{tabular}{|c|c|c|c|c|c|}
\hline Insect & Insect processing & Tested as ingredient or in a food & Method & $\mathrm{N}$ digestibility & Reference \\
\hline \multirow[t]{12}{*}{$\begin{array}{l}\text { Black soldier fly } \\
\text { larvae }\end{array}$} & Freeze-dried, ground & Ingredient & $\begin{array}{l}\text { In vitro digestion for } \\
\text { dogs }\end{array}$ & $89.7 \%$ & Bosch et al. (2014) \\
\hline & Freeze-dried, ground & Ingredient & $\begin{array}{l}\text { In vitro digestion for } \\
\text { dogs }\end{array}$ & $87.7 \%$ & Bosch et al. (2016) \\
\hline & Defatted, dried, ground & $\begin{array}{l}\text { Food, extruded with unknown } \\
\text { inclusion, contributing } 30 \% \text { of CP }\end{array}$ & $\begin{array}{l}\text { Faecal digestibility in } \\
\text { dogs }(n=10)\end{array}$ & $83.9 \%$ & Beynen (2018) \\
\hline & Defatted, dried, ground & $\begin{array}{l}\text { Food, extruded with } 20 \% \text { inclusion, } \\
\text { contributing } 31 \% \text { of } \mathrm{CP}\end{array}$ & $\begin{array}{l}\text { Faecal digestibility in } \\
\text { dogs }(n=6)\end{array}$ & $87.2 \%$ & $\begin{array}{l}\text { Yamka et al. } \\
\text { (2019) }\end{array}$ \\
\hline & Freeze-dried, ground, defatted & $\begin{array}{l}\text { Food, extruded with } 30 \% \text { DM } \\
\text { inclusion, contributing } 52 \% \text { of } \mathrm{CP}\end{array}$ & $\begin{array}{l}\text { Faecal digestibility in } \\
\text { dogs }(n=6)\end{array}$ & $80.5 \%$ & Meyer et al. (2019) \\
\hline & Freeze-dried, ground, defatted & $\begin{array}{l}\text { Food, pelleted with } 30 \% \text { DM } \\
\text { inclusion, contributing } 52 \% \text { of } \mathrm{CP}\end{array}$ & $\begin{array}{l}\text { Faecal digestibility in } \\
\text { dogs }(n=6)\end{array}$ & $78.2 \%$ & Meyer et al. (2019) \\
\hline & Defatted, dried, ground & $\begin{array}{l}\text { Food, pelleted food with } 1 \% \text { meal, } \\
\text { contributing } 1.6 \% \text { of } \mathrm{CP}\end{array}$ & $\begin{array}{l}\text { Faecal digestibility in } \\
\text { dogs }(n=3)\end{array}$ & $77.1 \%$ & Lei et al. (2019) \\
\hline & Defatted, dried, ground & $\begin{array}{l}\text { Food, pelleted food with } 2 \% \text { meal, } \\
\text { contributing } 3.2 \% \text { of } \mathrm{CP}\end{array}$ & $\begin{array}{l}\text { Faecal digestibility in } \\
\text { dogs }(n=3)\end{array}$ & $78.5 \%$ & Lei et al. (2019) \\
\hline & Defatted, dried, ground & $\begin{array}{l}\text { Food, extruded with unknown } \\
\text { inclusion, contributing } 30 \% \text { of CP }\end{array}$ & $\begin{array}{l}\text { Faecal digestibility in } \\
\text { cats }(n=10)\end{array}$ & $79.8 \%$ & Beynen (2018) \\
\hline & Defatted, dried, ground & $\begin{array}{l}\text { Food, extruded food with } 22 \% \\
\text { meal, contributing } 35 \% \text { of } \mathrm{CP}\end{array}$ & $\begin{array}{l}\text { Faecal digestibility in } \\
\text { cats }(n=9)\end{array}$ & $77.0 \%$ & $\begin{array}{l}\text { Paßlack and } \\
\text { Zentek (2018) }\end{array}$ \\
\hline & Defatted, dried, ground & $\begin{array}{l}\text { Food, extruded food with } 35 \% \\
\text { meal, contributing } 47 \% \text { of } \mathrm{CP}\end{array}$ & $\begin{array}{l}\text { Faecal digestibility in } \\
\text { cats }(n=7)\end{array}$ & $73.4 \%$ & $\begin{array}{l}\text { Paßlack and } \\
\text { Zentek (2018) }\end{array}$ \\
\hline & Defatted, dried, ground & $\begin{array}{l}\text { Food, extruded with } 20 \% \text { inclusion, } \\
\text { contributing } 31 \% \text { of } \mathrm{CP}\end{array}$ & $\begin{array}{l}\text { Faecal digestibility in } \\
\text { cats }(n=7)\end{array}$ & $74.9 \%$ & $\begin{array}{l}\text { Yamka et al. } \\
\text { (2019) }\end{array}$ \\
\hline Housefly larvae & Freeze-dried, ground & Ingredient & $\begin{array}{l}\text { In vitro digestion for } \\
\text { dogs }\end{array}$ & $93.3 \%$ & Bosch et al. (2016) \\
\hline \multirow[t]{3}{*}{ Banded crickets } & Roasted, ground & $\begin{array}{l}\text { Food, extruded with } 8 \% \text { inclusion, } \\
\text { contributing } 20 \% \text { of } \mathrm{CP}\end{array}$ & $\begin{array}{l}\text { Faecal digestibility in } \\
\text { dogs }(n=8)\end{array}$ & $84.8 \%$ & $\begin{array}{l}\text { Kilburn et al. } \\
(2020)\end{array}$ \\
\hline & Roasted, ground & $\begin{array}{l}\text { Food, extruded with } 16 \% \text { inclusion, } \\
\text { contributing } 38 \% \text { of } \mathrm{CP}\end{array}$ & $\begin{array}{l}\text { Faecal digestibility in } \\
\text { dogs }(n=8)\end{array}$ & $86.0 \%$ & $\begin{array}{l}\text { Kilburn et al. } \\
(2020)\end{array}$ \\
\hline & Roasted, ground & $\begin{array}{l}\text { Food, extruded with } 24 \% \text { inclusion, } \\
\text { contributing } 57 \% \text { of } \mathrm{CP}\end{array}$ & $\begin{array}{l}\text { Faecal digestibility in } \\
\text { dogs }(n=8)\end{array}$ & $82.1 \%$ & $\begin{array}{l}\text { Kilburn et al. } \\
(2020)\end{array}$ \\
\hline \multirow[t]{4}{*}{ Yellow mealworm } & Freeze-dried, ground & Ingredient & $\begin{array}{l}\text { In vitro digestion for } \\
\text { dogs }\end{array}$ & $91.3 \%$ & Bosch et al. (2014) \\
\hline & Freeze-dried, ground & Ingredient & $\begin{array}{l}\text { In vitro digestion for } \\
\text { dogs }\end{array}$ & $92.5 \%$ & Bosch et al. (2016) \\
\hline & Defatted, dried, ground & $\begin{array}{l}\text { Food, extruded with unknown } \\
\text { inclusion, contributing } 30 \% \text { of CP }\end{array}$ & $\begin{array}{l}\text { Faecal digestibility in } \\
\text { dogs }(n=10)\end{array}$ & $83.6 \%$ & Beynen (2018) \\
\hline & Defatted, dried, ground & $\begin{array}{l}\text { Food, extruded with unknown } \\
\text { inclusion, contributing } 30 \% \text { of CP }\end{array}$ & $\begin{array}{l}\text { Faecal digestibility in } \\
\text { cats }(n=10)\end{array}$ & $80.4 \%$ & Beynen (2018) \\
\hline Lesser mealworm & Freeze-dried, ground & Ingredient & $\begin{array}{l}\text { In vitro digestion for } \\
\text { dogs }\end{array}$ & $91.5 \%$ & Bosch et al. (2014) \\
\hline
\end{tabular}

In dogs, apparent faecal $\mathrm{N}$ digestibility of foods containing BSFL ranged from 73.2 to $87.2 \%$ (Beynen, 2018; Lei et al., 2019; Meyer et al., 2019; Yamka et al., 2019) and a YMWcontaining food was $83.6 \%$ (Beynen, 2018). It should be noted that in the study of Lei et al. (2019) the BSFL contributed minimally to the total amount of crude protein and outcomes were based on only 3 dogs, which is deemed insufficient for digestibility testing (AAFCO, 2020; FEDIAF, 2019b). Meyer et al. (2019) estimated that the apparent faecal $\mathrm{N}$ digestibility of their BSFL meal was $83.1 \%$ when 
included in an extruded food and $83.4 \%$ when included in a pelleted food. Feeding dogs extruded foods with 8,16 or $24 \%$ inclusion of banded crickets resulted in apparent faecal $\mathrm{N}$ digestibility values of $84.8,86.0$ and $82.1 \%$, respectively (Kilburn et al., 2020). The average apparent faecal $\mathrm{N}$ digestibility of commercial dog foods can be considered to be close to 80\% (Daumas et al., 2012; Hendriks et al., 2013; Hervera, 2011; Kendall et al., 1982), suggesting that the insect meals are in the range of conventional protein sources. In cats, reported faecal $\mathrm{N}$ digestibility values of 73.4 to $79.8 \%$ have been reported for diets containing BSFL meal (Beynen, 2018; Paßlack and Zentek, 2018; Yamka et al., 2019) and 80.4\% for YMW (Beynen, 2018).

Dogs and cats have specific requirements for indispensable amino acids (AA). It is therefore of interest to evaluate how well the insect proteins match with the requirements of dogs and cats. As a proxy for the match, digestible indispensable AA scores (DIAAS) can be calculated in line with protein quality evaluations in human nutrition (FAO, 2013). The DIAAS-like values are calculated as (mg of digestible dietary indispensable AA in $1 \mathrm{~g}$ of the digestible insect protein) $/$ (mg of the minimum requirement of the same dietary indispensable AA in $1 \mathrm{~g}$ of the minimum protein requirement). The digestible indispensable AA (DIAA, \%) for each AA was based on the reported AA content multiplied by its ileal digestibility coefficient. The value was divided by the amount of digestible protein based on reported crude protein content and digestibility coefficient for all amino acids. The minimum protein requirements for growing (4 to 14 weeks of age) and adult dogs and growing and adult cats are taken from the National Research Council (NRC, 2006). The calculation is performed for each dietary indispensable AA and the lowest value is designated as the DIAAS and used as an indicator of dietary protein quality (FAO, 2013).

In Table 2, the digestible indispensable amino acids for BSFL, HFL and YMW are shown, which are based on ileal digestibility studies in chickens. The lowest DIAAS values for BSFL were found for methionine (0.65-1.02) when considering the requirements of growing cats and for methionine (0.81-1.01) or threonine (1.03-1.14) when considering the requirements of growing dogs. For adult cats the lowest values were for arginine (0.83-1.04) or leucine (1.03-1.14) and for adult dogs this was for methionine (0.390.61). For HFL the lowest values were found for leucine for both growing and adult cats and growing dogs (DIAAS of $1.25,1.11$ and 1.24 , respectively) and for adult dogs this was methionine (0.93). For YMW methionine was first limiting growing and adult dogs and cats (DIAAS of 0.97, 0.55 and 0.92 , respectively) and for adult cats this was leucine (0.90). For poultry meal, one of the most used protein sources in pet foods, the first limiting AA were methionine for kittens (DIAAS value of 0.53) and tryptophan for growing and adult dogs and adult cats $(0.54,0.39$ and 0.66 , respectively) (based on data from Deng et al., 2016). Because growing dogs might receive foods that are close to their requirements (see Van Rooijen et al., 2014), understanding the content and bioavailability of indispensable AA is in particular important for pet food manufacturers that formulate insectbased foods for puppies.

\section{Stool quality}

Owners are in close contact with the stools of their pets and may associate stool attributes (volume, consistency, odour, colour, and ease and frequency of defaecation) to intestinal health and to the overall nutritional quality of the food. Furthermore, owners seek convenience when picking up stools after their beloved dog or removing these from the litter box of their cat. Stool quality is often also assessed in studies that evaluate the acceptance or digestibility of foods. The stool consistency is commonly evaluated using a 5-point scoring system (e.g. Laflamme et al., 2011; Moxham, 2001) with consistency varying from hard, dry pellets to a watery liquid that can be poured. Ideal stools are generally considered to have a firm to soft consistency and retain their shape. Stool consistency was ideal in dogs fed the extruded and pelleted foods containing 30\% BSFL (Meyer et al., 2019). Yamka et al. (2019) reported that all the foods containing either 20\% BSFL meal or 5\% oil resulted in ideal stool consistency in dogs and did not impact stool consistency in cats relative to the control food. Stools remained well-formed when dogs were fed extruded foods with increasing levels $(8,16$ or 24\%) of banded cricket meal (Kilburn et al., 2020). Though the number of studies is still limited, it seems that including insect meals in dry extruded pet foods do not disturb intestinal functioning and lead to acceptable stool consistencies. Other stool quality attributes remain to be studied.

\section{Overall health}

Commercial pet foods that are marketed as being nutritionally complete should support the health of the dog or cat over the long-term. At this moment, only two studies have evaluated the impact of insect-based dog foods on the nutritional status and health of dogs and no studies are available that evaluated this in cats. In one study (Lei et al., 2019) dogs ( $\mathrm{n}=3$ per dietary treatment) were fed a dry pelleted food containing 0,1 or $2 \%$ defatted, dried and ground BSFL meal (contributing 1.6 or $3.2 \%$ of total crude protein) for 6 weeks after which blood samples were taken for several haematological and biochemical parameters and profiling of lipids and minerals. Furthermore, these dogs were intraperitoneally challenged with Escherichia coli lipopolysaccharide and their immune responses were monitored. Though some changes were noted, i.e. linear increasing levels of albumin and calcium and at 6 hours after the challenge and linear decreasing levels of tumour necrosis factor- $\alpha$ and increasing levels of glutathione 
Table 2. Digestible indispensable amino acids (DIAA, \%) and their scores (DIAAS) of insects calculated from data reported in the literature.

\section{Insect}

\section{Black soldier fly larvae}

更

DIAA ${ }^{2}$

\section{Housefly larvae}

Yellow mealworm

Reference $^{1} \quad$ I

$\begin{array}{lll}\text { Arginine } & 6.42 & 3.99 \\ \text { Histidine } & 3.65 & 1.85 \\ \text { Isoleucine } & 3.08 & 3.61 \\ \text { Leucine } & 7.27 & 5.64 \\ \text { Lysine } & 4.09 & 3.95 \\ \text { Methionine } & 1.51 & 1.26 \\ \text { Phenylalanine } & 3.62 & 3.20 \\ \text { Threonine } & 4.54 & 2.95 \\ \text { Tryptophan } & - & - \\ \text { Valine } & 5.44 & 5.75\end{array}$

\begin{tabular}{|c|c|c|c|c|c|c|c|c|c|c|}
\hline DIAAS $^{3}$ & Kittens & Puppies & Kittens & Puppies & Kittens & Puppies & Kittens & Puppies & Kittens & Puppies \\
\hline Arginine & 1.50 & 1.60 & 0.93 & 1.14 & $1.13-1.37$ & $1.38-1.67$ & 1.37 & 1.67 & 1.31 & 1.83 \\
\hline Histidine & 2.53 & 1.84 & 1.28 & 1.07 & $1.69-2.20$ & $1.42-1.84$ & 2.36 & 1.98 & 2.19 & 2.12 \\
\hline Isoleucine & 1.29 & 1.39 & 1.51 & 1.25 & $1.74-1.91$ & $1.44-1.58$ & 1.69 & 1.40 & 1.68 & 1.07 \\
\hline Leucine & 1.28 & 1.00 & 1.00 & 0.99 & $1.15-1.24$ & $1.14-1.24$ & 1.25 & 1.24 & 1.01 & 1.27 \\
\hline Lysine & 1.08 & 1.74 & 1.04 & 1.01 & $1.65-1.88$ & $1.60-1.82$ & 2.25 & 2.19 & 1.79 & 1.05 \\
\hline Methionine & 0.78 & 1.15 & 0.65 & 0.81 & $0.78-1.02$ & $0.97-1.28$ & 1.55 & 1.94 & 0.92 & 0.97 \\
\hline Phenylalanine & 1.63 & 1.31 & 1.44 & 1.11 & $1.53-2.05$ & $1.17-1.58$ & 3.29 & 2.53 & 1.71 & 1.25 \\
\hline Threonine & 1.57 & 0.91 & 1.02 & 0.82 & $1.28-1.42$ & $1.02-1.14$ & 2.11 & 1.68 & 1.14 & 1.26 \\
\hline Tryptophan & - & - & - & - & $1.37-2.19$ & $0.99-1.58$ & 10.88 & 7.86 & 1.81 & 1.81 \\
\hline Valine & 1.92 & 1.71 & 2.03 & 1.92 & $1.81-2.57$ & $1.71-2.43$ & 1.74 & 1.65 & 1.31 & 1.83 \\
\hline DIAAS $^{4}$ & Cats & Dogs & Cats & Dogs & Cats & Dogs & Cats & Dogs & Cats & Dogs \\
\hline Arginine & 1.33 & 1.83 & 0.83 & 1.14 & $1.00-1.22$ & $1.38-1.67$ & 1.21 & 1.67 & 1.16 & 1.60 \\
\hline Histidine & 2.24 & 1.95 & 1.14 & 0.99 & $1.50-1.95$ & $1.30-1.69$ & 2.10 & 1.82 & 1.95 & 1.69 \\
\hline Isoleucine & 1.15 & 0.82 & 1.34 & 0.96 & $1.55-1.70$ & $1.11-1.22$ & 1.51 & 1.08 & 1.50 & 1.07 \\
\hline Leucine & 1.14 & 1.08 & 0.89 & 0.84 & $1.02-1.11$ & $0.96-1.05$ & 1.11 & 1.05 & 0.90 & 0.85 \\
\hline Lysine & 2.42 & 1.17 & 2.34 & 1.13 & $3.70-4.20$ & $1.78-2.02$ & 5.04 & 2.43 & 4.01 & 1.93 \\
\hline Methionine & 1.80 & 0.47 & 1.49 & 0.39 & $1.79-2.35$ & $0.47-0.61$ & 3.58 & 0.93 & 2.13 & 0.55 \\
\hline Phenylalanine & 1.45 & 0.80 & 1.28 & 0.71 & $1.36-1.82$ & $0.75-1.01$ & 2.93 & 1.63 & 1.52 & 0.84 \\
\hline Threonine & 1.40 & 1.07 & 0.91 & 0.69 & $1.14-1.26$ & $0.87-0.97$ & 1.87 & 1.43 & 1.01 & 0.77 \\
\hline Tryptophan & - & - & - & - & $1.22-1.94$ & $0.72-1.15$ & 9.67 & 5.71 & - & - \\
\hline Valine & 1.71 & 1.12 & 1.80 & 1.18 & $1.61-2.28$ & $1.05-1.49$ & 1.55 & 1.01 & 1.61 & 1.05 \\
\hline
\end{tabular}

${ }_{1}^{1}$ I = De Marco et al. (2015) reporting apparent ileal digestibility coefficients for oven-dried ground insects in 35-day old broiler chickens calculated based on the values found for the basal diet without the insect meal; II = Schiavone et al. (2017) reporting apparent ileal digestibility coefficients for oven-dried ground and partially defatted insects in 35-day old broiler chickens calculated based on the values found for the basal diet without the insect meal; III = Do et al. (2020) reporting corrected ileal digestibility coefficients for freeze-dried and ground black soldier fly larvae varying in age $(0,11,14,18,23$ or 29 days) in precision-fed cecectomised roosters fed the insect meal; IV = Hall et al. (2018) reporting true ileal digestibility coefficients for oven-cooked and ground insects in 28-day old broiler chickens calculated using multiple linear regression technique.

${ }^{2}$ Digestible indispensable amino acid content as a percentage of digestible crude protein content. The latter was based on the dietary crude protein content multiplied by the average digestibility value based on all reported amino acids.

${ }^{3}$ For minimal requirement data (NRC, 2006) for kittens in \% of crude protein: arginine, 4.278; histidine, 1.444; isoleucine, 2.389; methionine, 1.944; leucine, 5.667; lysine, 3.778; phenylalanine, 2.222; threonine, 2.889; tryptophan, 0.722 ; valine, 2.833. For puppies ( 4 to 14 weeks of age) these values are: arginine, $3.500 ;$ histidine, 1.722; isoleucine, 2.889; methionine, 1.556; leucine, 5.722; lysine, 3.889; phenylalanine, 2.289; threonine, 4.611; tryptophan, 1.000; valine, 3.000.

${ }^{4}$ For minimal requirement data or adequate intake data (in italics) (NRC, 2006) for adult cats in \% of crude protein: arginine, 4.813; histidine, 1.625; isoleucine, 2.688; methionine, 0.844 ; leucine, 6.375; lysine, 1.688; phenylalanine, 2.500; threonine, 3.250; tryptophan, 0.813; valine, 3.188. For adult dogs these values are: arginine, 3.500; histidine, 1.875; isoleucine, 3.750; methionine, 3.250; leucine, 6.750; lysine, 3.500; phenylalanine, 4.500; threonine, 4.250; tryptophan, 1.375; valine, 4.875. 
peroxidase, the number of dogs per treatment is too small to make conclusions about potential health effects of foods containing small amounts (1 or $2 \%$ ) of BSFL meal. Dogs ( $n=8$ per dietary treatment) fed a dry extruded food with increasing levels $(0,8,16$ or $24 \%)$ of roasted and ground cricket-meal (contributing 20, 38 or $57 \%$ of total crude protein) for 29 days had on average haematology and chemistry profiles within the reference ranges for healthy dogs (Kilburn et al., 2020). For some individual dogs, values were just outside the ranges, but details about the number of dogs or exact deviations were unfortunately not provided by the authors. It is clear that more long-term studies are required to evaluate adequacy and safety of insect-based pet foods in both dogs and cats.

\section{Biofunctionality}

Pet foods are often marketed to have specific biofunctionalities that could support pets in maintaining their health or even improve the health when the pet suffers from a specific health condition (clinical foods). Insect-based foods for dogs and cats are marketed as being 'hypoallergenic' (Beynen, 2018). Dogs and cats may develop adverse reactions to foods resulting in dermatological and/or gastro-intestinal problems like inflammation. As with food allergies, specific protein sources are commonly suspected and a change to such a hypoallergenic food with a protein source that is unfamiliar to the immune system is suggested. To the authors' knowledge, no studies are published that evaluated the effectiveness of these insect-based hypoallergenic foods in affected dogs or cats.

Apart from being a protein source for hypoallergenic foods, various health-promoting properties (e.g. hypolipidaemic, hypocholesterolaemic, immune-stimulatory, antibacterial, antiviral, antitumor) of insects or insect-derived compounds like chitin and peptides have been investigated (for reviews see Bulet et al., 1999; Chernysh et al., 2002; Gasco et al., 2018). There are currently no data published that support the notion of a health-promoting effect of an insect-based pet food. Furthermore, translating findings in other species to dogs or cats is often not possible because of the profound different species-specific characteristics (e.g. in physiology, metabolism and immune systems).

Lastly, the undigestible fractions of foods are important for the intestinal health as these can stimulate motility and act as a substrate that stimulates the growth of beneficial or detrimental microbiota and production metabolites that impact the host's health. The cuticle of insects contains chitin, a linear polymer of $\beta-(1-4) \mathrm{N}$-acetyl-d-glucosamine units, which is embedded in a matrix with proteins that vary in types and degree of sclerotization (Andersen et al., 1995). The cuticle properties vary within an insect and between insect species depending on the required functionalities. This part of the insect likely forms the undigestible fraction that would enter the large intestine of dogs and cats and potentially be degraded by the residing microbiota. The in vitro fermentability of the undigested fractions of BSFL, HFL and YMW by faecal microbiota from dogs (Bosch et al., 2016) and cats (Bosch and Post, 2019) was found to be low. This could imply that the undigested fraction of these insects would act more like a bulking fibre such as cellulose. The number of faecal donors used in these studies was, however, low and the dogs and cats (and their microbiomes) were not adapted to insect-based pet foods. Also a recent study in which dogs were fed extruded foods with banded cricket meal for 29 days reported changes in only a few specific taxa of the microbiome (Jarrett et $a l ., 2019)$, which suggests that the prebiotic potential of the indigestible fraction of the cricket meal was low. However, more extensive studies are required to explore animal/microbiome variation and potential adaptation of microbiota to ferment compounds like chitin from different insect species as well as to explore the impact on gut health.

\section{Sustainability}

Of the 12 commercial hypoallergenic insect-based foods for dogs and cats evaluated by Beynen (2018), eight included a claim that insects are a sustainable protein source. Insects are energy-efficient due to their poikilothermic nature and have a relatively high proportion of edible weight. Higher feed conversion efficiencies can therefore be achieved by insects than by conventional livestock species like ruminants, pigs and poultry. Based on life cycle assessment, insect protein may have a lower environmental impact (e.g. lower land use, lower water use, less emission of $\mathrm{CO}_{2}-$ equivalents) than edible ruminant, pig or poultry protein (Van Huis and Oonincx, 2017). As with the livestock species, insect species differ in their environmental impact and, in particular, what the insects are fed has an enormous influence. For example, production of $1 \mathrm{~kg}$ YMW protein is estimated to generate 6 to $14 \mathrm{~kg} \mathrm{CO}_{2}$-equivalents (Oonincx and De Boer, 2012; Thévenot et al., 2018) whereas this is approximately $3 \mathrm{~kg}$ when BSFL are fed a feed-grade substrate and approximately $19 \mathrm{~kg}$ when fed a food-grade substrate (Bosch et al., 2019). Insect rearing companies are still optimising their production processes by testing, for example, the genetics and nutrition of insects. It can be expected that their production will become more efficient. Legislation might change and new low-value organic streams may be unlocked for upcycling by insects in a safe way. These developments will further reduce the environmental impact of insect protein meals.

The benchmark to which insect protein generally is compared is meat (e.g. beef, pork, chicken), which in general has indeed an overall higher environmental impact. For pet foods, however, it makes sense to not use meat, but their co-products (e.g. meat meals for dry foods and organs for wet foods) as these are the conventional protein 
sources used in pet foods and those that will most likely be replaced by insect meal. Peer-reviewed studies evaluating environmental impact of pet foods falsely assumed meat as main protein source (e.g. Okin, 2017; Su et al., 2018) and do not provide reference data on the impact of these conventional pet food ingredients. A report of Blonk Consultants, however, estimated an impact of about $1 \mathrm{~kg}$ $\mathrm{CO}_{2}$-equivalents per $\mathrm{kg}$ protein for a mixed meal and $2 \mathrm{~kg}$ per $\mathrm{kg}$ protein for a poultry meal (Koukouna and Broekema, 2017), which is lower than that for BSFL and YMW. Thus, the support of the claim that insects are a sustainable protein source is not unambiguous and a matter of selecting a benchmark. Furthermore, it also depends on the method of quantification and considerations of what specific aspects of sustainability (environmental, economic, societal) are of interest.

\section{Concluding remarks}

The 'buzz' in society around insects as sustainable and healthy new protein sources has opened the market for insect-based pet food products. The insect-based hypoallergenic foods are now an additional option to owners with dogs or cats suffering from supposed or diagnosed food sensitivity. Products like insect-based snacks are also available on the market. The latter types of products are more subject to volatile trends and are less likely to prevail when the buzz slowly silences and new trends arise. For the sake of the reputation of insects as a novel quality ingredient and the pet food industry as a whole, it is essential that safety and efficacy testing is performed and results are shared with the community. Multiple studies evaluated aspects of the nutritional quality of various insect species but the impact of long-term feeding on the nutritional status and health in dogs and cats are still largely unexplored. At the same time, there is considerable interest in the potential bioactives present in insects resulting in studies in pigs, poultry and other production animals from which pet food sector can learn from. How these may impact (promote or harm) the health of dogs and cats is presently unknown. This lack of knowledge provides an additional argument to warrant long-term studies in both dogs and cats fed foods based on insect meals and those containing specific isolated components from insects. If proven to be positive and effective, applications of insects can be expanded to clinical foods or foods supporting health and wellness.

To what extent insect meals will have even wider applications in pet foods is difficult to predict. The insect sector continues to develop as it can play a role in making the global food production system more resource-efficient and productive at the same time. In addition, Europe is striving to become more self-sufficient regarding feed proteins, further fuelling the development of alternative protein-rich feed ingredients like insects but also multiple others including algae, bacterial single cell proteins and legumes. Ongoing developments in automation and processing technologies, selective breeding and the nutrition of insects will further increase production volumes and reduce the economic cost as well as the environmental impact per unit of protein. This will make insect proteins more competitive with conventional protein sources used in the pet food industry and those used in the aquaculture and livestock sectors. At the same time the global demand for animal-derived foods will continue to grow in fastdeveloping countries. Meat, for example, is projected to grow from 2005/2007 to 2050 with 76\% (Alexandratos and Bruinsma, 2012). The increasing volumes of animalderived foods will also make more co-products available for pet food production. Apart from price and availability, wider applications of insects in pet foods would also likely depend on the evolving reputation that edible insects have in society. Central aspects for acceptance of edible insects in humans include trust, willingness-to-eat, overcoming disgust and neophobic reactions, and sensory attributes but it is also essential to consider ethical aspects like speciesspecific mass rearing conditions, transportation and killing methods (Rumpold and Langen, 2020). Furthermore, pet owners may deem specific residual organic sources to rear insects acceptable whereas they perceive other sources as unsafe or unsanitary. From a resource use efficiency point of view, however, it is of interest to grow insects on residual organic sources that are currently not used in feed for livestock or aquaculture. It is therefore of particular interest to better understand pet owner views on the use of specific organic sources to rear insects and the consequences for environmental impact, relative to animal-derived coproducts conventionally used in pet foods.

\section{Acknowledgements}

This research was funded by Wageningen University \& Research and University of Illinois at Urbana-Champaign. Both authors contributed fundamentally to the present manuscript.

\section{Conflict of interest}

There are no conflicts of interest.

\section{References}

Association of American Feed Control Officials (AAFCO), 2020. Official publication. AAFCO Incorporated, Atlanta, GA, USA,

Ahlstrøm, Ø. and Skrede, A., 1998. Comparative nutrient digestibility in dogs, blue foxes, mink and rats. Journal of Nutrition 128: S26762677.

Aldrich, G.C. and Koppel, K., 2015. Pet food palatability evaluation: a review of standard assay techniques and interpretation of results with a primary focus on limitations. Animals 5: 43-55. 
Alexandratos, N. and Bruinsma, J., 2012. World agriculture towards 2030/2050; the 2012 revision. Food and Agriculture Organization of the United Nations, Rome, Italy.

Andersen, S.O., Hojrup, P. and Roepstorff, P., 1995. Insect cuticular proteins. Insect Biochemistry and Molecular Biology 25: 153-176.

Bayly, C.P., 1976. Observations on the food of the feral cat (Felis catus) in an arid environment. South Australian Naturalist 51: 22-24.

Beaton, L., 2014. US petfood market update: specialty petfoods driving industry growth. Petfood Industry 56: 20-25.

Beynen, A.C., 2018. Insect-based petfood. Creature Companion: 40-41. Bosch, G., Zhang, S., Oonincx, D.G.A.B. and Hendriks, W.H., 2014. Protein quality of insects as potential ingredients for dog and cat foods. Journal of Nutritional Science 3: e29.

Bosch, G., Hagen-Plantinga, E.A. and Hendriks, W.H., 2015. Dietary nutrient profiles of wild wolves: insights for optimal dog nutrition? British Journal of Nutrition 113: S40-S54.

Bosch, G., Vervoort, J.J.M. and Hendriks, W.H., 2016. In vitro digestibility and fermentability of selected insects for dog foods. Animal Feed Science and Technology 221: 174-184.

Bosch, G. and Post, M., 2019. Fermentability of undigested residues from insects in cats: an in vitro pilot study. In: Proceedings of the $23^{\text {rd }}$ Congress of the European Society of Veterinary and Comparative Nutrition, 18-20 September 2019, Turin, Italy. pp. 224.

Bosch, G., Van Zanten, H.H.E., Zamprogna, A., Veenenbos, M., Meijer, N.P., Van der Fels-Klerx, H.J. and Loon, J.J.A., 2019. Conversion of organic resources by black soldier fly larvae: legislation, efficiency and environmental impact. Journal of Cleaner Production 222: 355-363.

Bradshaw, J.W.S. and Cook, S.E., 1996. Patterns of pet cat behaviour at feeding occasions. Applied Animal Behaviour Science 47: 61-74.

Bulet, P., Hetru, C., Dimarcq, J.L. and Hoffman, D., 1999. Antimicrobial peptides in insects; structure and function. Developmental \& Comparative Immunology 23: 329-344.

Chernysh, S., Kim, S.I., Bekker, G., Pleskach, V.A., Filatova, N.A., Anikin, V.B., Platonov, V.G. and Bulet, P., 2002. Antiviral and antitumor peptides from insects. Proceedings of the National Academy of Sciences of the United States of America 99: 1262812632.

Daumas, C., Paragon, B.-M., Thorin, C., Martin, L., Dumon, H., Ninet, S. and Nguyen, P., 2012. Evaluation of eight commercial dog diets. Journal of Nutritional Science 3: e63.

Day, J.E.L., Kergoat, S. and Kotrschal, K., 2009. Do pets influence the quantity and choice of food offered to them by their owners: lessons from other animals and the pre-verbal human infant? $\mathrm{CAB}$ Reviews: Perspectives in Agriculture, Veterinary Science, Nutrition and Natural Resources 4: 1-12.

De Marco, M., Martínez, S., Hernandez, F., Madrid, J., Gai, F., Rotolo, L., Belforti, M., Bergero, D., Katz, H., Dabbou, S., Kovitvadhi, A., Zoccarato, I., Gasco, L. and Schiavone, A., 2015. Nutritional value of two insect larval meals (Tenebrio molitor and Hermetia illucens) for broiler chickens: apparent nutrient digestibility, apparent ileal amino acid digestibility and apparent metabolizable energy. Animal Feed Science and Technology 209: 211-218.
Deng, P., Utterback, P.L., Parsons, C.M., Hancock, L., Swanson, K.S., 2016. Chemical composition, true nutrient digestibility, and true metabolizable energy of novel pet food protein sources using the precision-fed cecectomized rooster assay. Journal of Animal Science 94: 3335-3342.

Do, S., Koutsos, E.A., Utterback, P.L., Parsons, C.M., De Godoy, M.R.C. and Swanson, K.S., 2020. Nutrient and AA digestibility of black soldier fly larvae differing in age using the precision-fed cecectomized rooster assay. Journal of Animal Science 98: skz363.

Driscoll, C.A., Menotti-Raymond, M., Roca, A.L., Hupe, K., Johnson, W.E., Geffen, E., Harley, E.H., Delibes, M., Pontier, D., Kitchener, A.C., Yamaguchi, N., O'Brien, S.J. and Macdonald, D.W., 2007. The Near Eastern origin of cat domestication. Science 317: 519-523.

Faber, T.A., Bechtel, P.J., Hernot, D.C., Parsons, C.M., Swanson, K.S., Smiley, S. and Fahey Jr, G.C., 2010. Protein digestibility evaluations of meat and fish substrates using laboratory, avian, and ileally cannulated dog assays. Journal of Animal Science 88: 1421-1432.

FEDIAF, 2019a. Facts \& figures 2019. European Pet Food Industry Federation, Brussels, Belgium.

FEDIAF, 2019b. Nutritional guidelines for complete and complementary pet food for cats and dogs. European Pet Food Industry Federation, Brussels, Belgium.

Food and Agriculture Organisation (FAO), 2013. Dietary protein quality evaluation in human nutrition. FAO, Auckland, New Zealand.

Gasco, L., Finke, M. and Van Huis, A., 2018. Can diets containing insects promote animal health? Journal of Insects as Food and Feed 4: 1-4.

Hall, H.N., Masey O’Neill, H.V., Scholey, D., Burton, E., Dickinson, M. and Fitches, E.C., 2018. Amino acid digestibility of larval meal (Musca domestica) for broiler chickens. Poultry Science 97: 12901297.

Hendriks, W.H., Emmens, M.M.A., Trass, B. and Pluske, J.R., 1999. Heat processing changes the protein quality of canned cat foods as measured with a rat bioassay. Journal of Animal Science 77: 669-676.

Hendriks, W.H., Van Baal, J. and Bosch, G., 2012. Ileal and faecal protein digestibility measurement in monogastric animals and humans: a comparative species view. British Journal of Nutrition 108: S247-S257.

Hendriks, W.H., Thomas, D.G., Bosch, G. and Fahey Jr, G.C., 2013. Comparison of ileal and total tract nutrient digestibility of dry dog foods. Journal of Animal Science 91: 3807-3814.

Hervera, M., Baucells, M.D., González, G., Pérez, E. and Castrillo, C., 2009. Prediction of digestible protein content of dry extruded dog foods: comparison of methods. Journal of Animal Physiology and Animal Nutrition 93: 366-372.

Hervera, M., 2011. Methods for predicting the energy value of dog foods. Universitat de Autònoma de Barcelona, Barcelona, Spain.

Jarrett, J.K., Carlson, A., Serao, M.R., Strickland, J., Serfilippi, L. and Ganz, H.H., 2019. Diets with and without edible cricket support a similar level of diversity in the gut microbiome of dogs. PeerJ 7: e7661.

Johnson, M.L., Parsons, C.M., Fahey Jr, G.C., Merchen, N.R. and Aldrich, C.G., 1998. Effects of species raw material source, ash content, and processing temperature on amino acid digestibility of animal by-product meals by cecectomized roosters and ileally cannulated dogs. Journal of Animal Science 76: 1112-1122. 
Kendall, P.T., Blaza, S.E. and Holme, D.W., 1982. Assessment of endogenous nitrogen output in adult dogs of contrasting size using a protein-free diet. Journal of Nutrition 112: 1281-1286.

Kilburn, L.R., Carlson, A.T., Lewis, E. and Rossoni Serao, M.C., 2020. Cricket (Gryllodes sigillatus) meal fed to healthy adult dogs does not affect general health and minimally impacts apparent total tract digestibility. Journal of Animal Science 98: 1-8.

Konecny, M.J., 1987. Food habits and energetics of feral house cats in the Galápagos Islands. Oikos 50: 24-32.

Koukouna, E. and Broekema, R., 2017. Carbon footprint assessment of cat 3 meal for pet food applications. Blonk Consultants, Gouda, the Netherlands.

Laflamme, D.P., Xu, H. and Long, G.M., 2011. Effect of diets differing in fat content on chronic diarrhea in cats. Journal of Veterinary Internal Medicine 25: 230-235.

Lei, X.J., Kim, T.H., Park, J.H. and Kim, I.H., 2019. Evaluation of supplementation of defatted black soldier fly (Hermetia illucens) larvae meal in beagle dogs. Annals of Animal Science 19: 767-777.

Leonard, J.A., Wayne, R.K., Wheeler, J., Valadez, R., Guillén, S. and Vilà, C., 2002. Ancient DNA evidence for old world origin of New World dogs. Science 298: 1613-1616.

Llewellyn, L.M. and Uhler, F.M., 1952. The foods of fur animals of the Patuxent Research Refuge, Maryland. American Midland Naturalist 48: 193-203.

Makkar, H.P.S., Tran, G., Heuzé, V. and Ankers, P., 2014. State-ofthe-art on use of insects as animal feed. Animal Feed Science and Technology 197: 1-33.

Malo, A.F., Lozano, J., Huertas, D.L. and Virgos, E., 2004. A change of diet from rodents to rabbits (Oryctolagus cuniculus). Is the wildcat (Felis silvestris) a specialist predator? Journal of Zoology 263: 401-407.

Meyer, L.F., Kölln, M. and Kamphues, J., 2019. Hundefutter mit Insekten? Untersuchungen zu Mischfuttermitteln mit Larven der Schwarzen Soldatenfliege als Proteinquelle. Kleintierpraxis 64: 124-135.

Moxham, G., 2001. WALTHAM feces scoring system - a tool for veterinarians and pet owners: how does your pet rate? WALTHAM Focus 11: 24-25.

National Research Council (NRC), 2006. Nutrient requirements of dogs and cats. National Academies Press, Washington, DC, USA.

O'Haire, M., 2010. Companion animals and human health: benefits, challenges, and the road ahead. Journal of Veterinary Behavior: Clinical Applications and Research 5: 226-234.

Okin, G., 2017. Environmental impacts of food consumption by dogs and cats. PLoS ONE 12: e0181301.

Oonincx, D.G.A.B. and De Boer, I.J.M., 2012. Environmental impact of the production of mealworms as a protein source for humans - a life cycle assessment. PLoS ONE 7: e51145.

Parmalee, P.W., 1953. Food habits of the feral house cat in east-central Texas. Journal of Wildlife Management 17: 375-376.

Paßlack, N. and Zentek, J., 2018. Akzeptanz, Verträglichkeit und scheinbare Nährstoffverdaulichkeit von Alleinfuttermitteln auf Basis von Hermetia-illucens-Larvenmehl bei Katzen. Tierärztliche Praxis Kleintiere 46: 213-221.
Pearre, S. and Maass, R., 1998. Trends in the prey size-based trophic niches of feral and house cats Felis catus L. Mammal Review 28: 125-139.

Plantinga, E.A., Bosch, G. and Hendriks, W.H., 2011. Estimation of the dietary nutrient profile of free-roaming feral cats: possible implications for nutrition of domestic cats. British Journal of Nutrition 106: S35-S48.

Podberscek, A.L., Paul, E.S. and Serpell, J.A., 2000. Companion animals and us: exploring the relationships between people and pets. Cambridge University Press, Cambridge, UK, 335 pp.

Rumpold, B.A. and Schlüter, O.K., 2013. Nutritional composition and safety aspects of edible insects. Molecular Nutrition and Food Research 57: 802-823.

Rumpold, B.A. and Langen, N., 2020. Consumer acceptance of edible insects in an organic waste-based bio-economy. Current Opinion in Green and Sustainable Chemistry 23: 80-84.

Schiavone, A., De Marco, M., Martínez, S., Dabbou, S., Renna, M., Madrid, J., Hernandez, F., Rotolo, L., Costa, P., Gai, F. and Gasco, L., 2017. Nutritional value of a partially defatted and a highly defatted black soldier fly larvae (Hermetia illucens L.) meal for broiler chickens: apparent nutrient digestibility, apparent metabolizable energy and apparent ileal amino acid digestibility. Journal of Animal Science and Biotechnology 8: 51.

Schleicher, M., Cash, S.B. and Freeman, L.M., 2019. Determinants of pet food purchasing decisions. Canadian Veterinary Journal 60: 644-650.

Smeets-Peeters, M.J.E., Minekus, M., Havenaar, R., Schaafsma, G. and Verstegen, M.W.A., 1999. Description of a dynamic in vitro model of the dog gastrointestinal tract and an evaluation of various transit times for protein and calcium. ATLA Alternatives to Laboratory Animals 27: 935-949.

Statista, 2020a. Number of dogs in the United States from 2000 to 2017. Available at: https://www.statista.com/statistics/198100/ dogs-in-the-united-states-since-2000/

Statista, 2020b. Number of cats in the United States from 2000 to 2017. Available at: https://www.statista.com/statistics/198102/ cats-in-the-united-states-since-2000/

$\mathrm{Su}, \mathrm{B} .$, Martens, P. and Enders-Slegers, M.-J., 2018. A neglected predictor of environmental damage: the ecological paw print and carbon emissions of food consumption by companion dogs and cats in China. Journal of Cleaner Production 194: 1-11.

Thévenot, A., Rivera, J.L., Wilfart, A., Maillard, F., Hassouna, M., Senga-Kiesse, T., Le Féon, S. and Aubin, J., 2018. Mealworm meal for animal feed: environmental assessment and sensitivity analysis to guide future prospects. Journal of Cleaner Production 170: 12601267.

Tjernsbekk, M.T., Tauson, A.H. and Ahlstrøm, Ø., 2014. Ileal, colonic and total tract nutrient digestibility in dogs (Canis familiaris) compared with total tract digestibility in mink (Neovison vison). Archives of Animal Nutrition 68: 245-261.

Tobie, C., Péron, F. and Larose, C., 2015. Assessing food preferences in dogs and cats: a review of the current methods. Animals 5: 126-137.

Van Huis, A. and Oonincx, D.G.A.B., 2017. The environmental sustainability of insects as food and feed. A review. Agronomy for Sustainable Development 37: 1-14. 
Van Rooijen, C., Bosch, G., Van der Poel, A.F.B., Wierenga, P.A., Alexander, L. and Hendriks, W.H., 2014. Reactive lysine content in commercially available pet foods. Journal of Nutritional Science 3: e35.

Vilà, C., Savoleinen, P., Maldonado, J.E., Amorim, I.R., Rice, J.E., Honeycutt, R.L., Crandall, K.A., Lundeberg, J. and Wayne, R.K., 1997. Multiple and ancient origins of the domestic dog. Science 276: 1687-1689.
Vinassa, M., Vergnano, D., Valle, E., Giribaldi, M., Nery, J., Prola, L., Bergero, D. and Schiavone, A., 2020. Profiling Italian cat and dog owners' perceptions of pet food quality traits. BMC Veterinary Research 16: 131.

Wall, T., 2018. Raw pet food sales growing despite health warnings. Petfood Industry 60: 24-27.

Yamka, R.M., Koutsos, E.A. and McComb, A., 2019. Evaluation of black soldier fly larvae as a protein and fat source in pet foods. Petfood Forum, Kansas City, MI, USA, pp. 8-9. 
